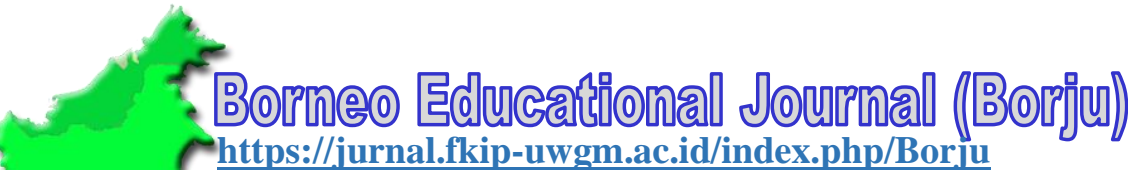 \\ E-ISSN: 2655-9323
}

February 2021, Vol. 3 No. 1

\section{University Students' Reflection on Learning English through Drama}

\section{Jihan $^{1}$, Hendriwanto ${ }^{2}$}

Universitas Swadaya Gunung Jati, Indonesia

Email correspondence: hendriwanto46@gmail.com

\begin{abstract}
Speaking skills is common in higher education and can be a significant source of anxiety and stress. This study was designed to measure the student's experience and self-esteem of speaking skills through drama performance. The research was conducted a qualitative interviewing method and analyzed using narrative inquiry. This study participants were English department students who have completed the drama subject in the fifth semester. The instrument used for collecting the data was an interview guide. This study revealed that drama makes students feel confident and self-esteem, freedom of expression, and improved speaking skills. It is supported by students' preparation in action and lecturers' feedback and appreciation in drama. The implications for lecturers involved in speaking performance include drama to consider their involvement in the process of student engagement in preparing for the performance. Because with the preparation time, the input and praise they receive can significantly affect their self-confidence, self-esteem, and the results of their appearance.
\end{abstract}

Keywords: drama; speaking skills, self-esteem

\begin{tabular}{|l|l|l|}
\hline DOI & : & https://doi.org/10.24903/bej.v3i1.705 \\
\hline Received & $:$ & January 2021 \\
\hline Accepted & $:$ & January 2021 \\
\hline Published & $:$ & February 2021 \\
\hline $\begin{array}{l}\text { Copyright and } \\
\text { License }\end{array}$ & $\begin{array}{l}\text { Authors retain copyright and grant the journal the right of first publication with } \\
\text { the work simultaneously licensed under a Creative Commons Attribution 4.0 } \\
\text { International License that allows others to share the work with an acknowledgment of }\end{array}$ \\
\hline \begin{tabular}{l} 
the work's authorship and initial publication in this journal. \\
\hline
\end{tabular} & \begin{tabular}{l} 
CC \\
\hline
\end{tabular} \\
\hline
\end{tabular}




\section{INTRODUCTION}

In language education, students need to learn speaking skills through verbal communication between people (Richard, 2008). For this purpose, the speaking course encourages students to learn a wide range of featured lessons such as eye contact, facial expressions, movement, tempo, pauses, voice tone changes, and pitch variations. These features allow students to have faith in conversation.

To do this, students need to develop speaking skills in a wide variety of contexts and circumstances. It is the perfect way to achieve effective communication. The students were conscious that their words and acts could be integrated into the play that would have taken place. Students' growth is not simply about reducing or removing risk and enhancing resilience but also about handling risk effectively. According to Jindal-Snape and Miller (2010), children with strong social and emotional growth are more likely to handle risk effectively. Drama is the way to provide opportunities for social play, where children might discuss solutions to the numerous social problems that have arisen (Hampshire 1996; ary1991; Peter 2000a, 2000b, 2003; Baim, Brookes, and Mountford 2002). Three research questions, are as follows: a) what is the students' preparation process for drama performance? b) how is the lecturer's involvement in drama?

\section{METHODOLOGY}

The writer used qualitative research since this study is Drama to Stimulate Students' Experience and Self-Esteem in Speaking Skills. In this sense, qualitative research focuses on examining social processes from individual subjects' viewpoints in a natural environment. Other than that, Creswell (2012, p. 16) indicated that qualitative research is an approach to examining and interpreting the significance of a person or a community to a social or human problem.

For the research design, the writer used qualitative interviewing. According to Mason (2002) all qualitative interviewing has several main features. An open dialog exchange occurs between two or more participants in a face-to-face or remote environment that is likely to have a relatively informal tone. There is a thematic, topic-centered, biographical, or narrative approach, with subjects or starting points of discussion flexibly addressed within a versatile context that allows for the inclusion of unexpected issues. Moreover, qualitative interviewing involves awareness of the information as it is put in its particular context; the information 
produced by interviews is beyond and based on the interpretation and understanding that is formed or reconstructed in the interview interaction.

The writer used the English students' Department to complete the drama subject in the fifth semester. The data collected from English students' responses through the interview. For this reason, the writer believed that these English students would provide informative data that the writers needed for this study. The instrument that the writer used is an adaptation of Tuan and Mai (2015). The interview's question consists of 5 questions.

According to Edward and Holland (2013: 15), interviews are referred to as 'gathering' data because the content is perceived to be a fact that is independent of the interviewee. The writer used narrative inquiry as an analysis data technique. The approach is called "thematic," "material" or "oriented theory" research. This included the repetitive reading, categorization of data extracts and their reorganization under the thematic heading. The core themes of narrative studies are discussed in various parts of the study, broken down into sub-themes and illustrated by narrative excerpts.

\section{FINDINGS}

\subsection{Prepare the Elements of Drama}

The participants are students who have taken drama courses in semester 5. To prepare drama performance, they take the time to practice speech, express themselves, deepen character, and memorize dialogue. They also learn independently in exercise. They are in the process of correcting their usual mistakes or problems. Nevertheless, through the drama, these mistakes and problems are even more fixed.
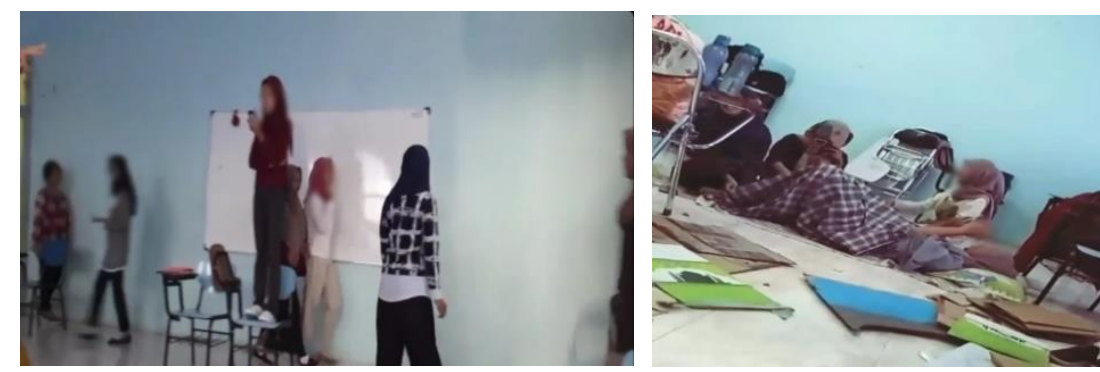

Illustration 1. Students preparation for a drama performance

I memorized the dialogue from the text of the script so it didn't seem too obvious to be memorizing. I always ask my friends for corrections regarding pronunciation, intonation, expression, and gestures .... I feel a sense of satisfaction and pride. Before the drama, I learned when there would be a speaking performance only, not every day. When performing I still like to carry small notes for preparation when I forget, I also always hold small objects to get rid of nervousness ... but after the drama, I got more and more understanding about the basics of writing and pronouncing English 
because I was involved in writing drama scripts that made My vocabulary and grammar are improving. (Student 1 )

There is a routine exercise that is carried out in stages where the duration of each exercise is around 3-4 hours starting from the start to the end scene which is done repeatedly ... I like to speak English but in this drama it is very challenging because I have to speak as well as play a role as well as an expression so I can deepen my role, but I'm nervous because I appear in front of my friends, mispronounce or express myself. Before the drama, I stuttered in speaking English, often giving pauses like "mm .." ... but after the drama, I felt my speaking skills were better because during drama practice I practiced every day, starting from pronunciation, intonation, and also gesture. (Student 2)

This is similar to Masoumi (2018) that the use of drama in language classroom is a strong opportunity for teaching languages. Through the use of drama, learners become acquainted with the grammatical structure in an exciting sense and learn how to use the language to convey power and educate. And Tuan and Mai view (2015) that the students' speaking performance was influenced by current awareness. Topical knowledge is characterized as the structure of knowledge in long-term memory (Bachman and Palmen 1996). In line with Tuan and Mai (2015), the student's speech success also influenced the tome for preparation.

\subsection{Lecturer' Feedback and Appreciation in English Drama}

The pupils feel that with feedback from the lecturers, they can learn and know what mistakes have happened to them. They also get some feedback and compliments, which makes them even more motivated.

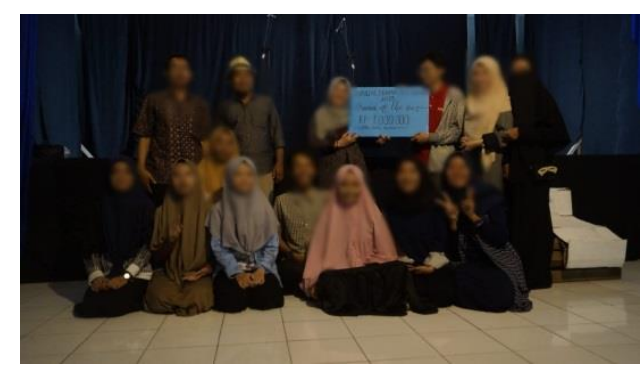

Illustration 2. Lecturers gave appreciation to students

before and after the drama, the lecturer was involved in providing input when I made a mistake, giving directions for the correct pronunciation by giving reference to video presentations on YouTube to help me improve my speaking skills. tells the right way of expression and intonation. I also use an electronic dictionary to help find out the correct pronunciation, the lecturer only controls the state during practice and checks the script. He wanted us to be more independent and create according to our wishes ... but still, give appreciation to our performances ... which made me more confident and there was a sense of satisfaction. (Student 1) 
because I play a male role, the lecturer evaluates the way I walk and my voice still looks like a woman. I continue to practice in front of a mirror or record my acting and then watch it again as an evaluation. Before the drama, the lecturer only evaluates in terms of pronunciation ... but after the drama, he evaluates everything from pronunciation to word choice. (Student 2)

This is similar to Tuan and Mai view (2015) that teacher input during speaking exercise also impacted student speech performance. Also Baker and Westrup (2003) that the teacher should always correct the error positively and with motivation.

\section{DISCUSSION}

The research results indicate that the participants are the English Education Department students who completed the drama subject in fifth semesters identified that they felt nervous and worried about English drama performance. On the other hand, the participants stated that several factors would enhance them in English drama performance and its benefits.

The participants said they felt nervous and worried about English drama because they lack confidence and worry about their pronunciation. This is similar to Lukitasari's (2008) view that the students' speaking performance was not strong because they did not master the three elements of speech, namely vocabulary, grammar, and pronunciation. And students' feelings of stress, anxiety, or nervousness can hinder their language learning and performance skills (Tanveer 2007).

The participants also explained some of the factors that could affect them in the English drama and its benefits. The first is the preparation of the participants to act. They need to prepare for the drama, to take the time to practice their voice, to articulate themselves, to develop their characters, and to memorize dialogue. From the practice of drama, they learn to correct their usual mistakes. This is in line with Tuan and Mai (2015) statement that the students's speech performance is also influenced by time for practice. The second is the input from the teachers about the english drama that they were able to learn and realize what the errors had happened to them. And they have received some reviews and compliments that make them even more inspired. This study is in line with Tuan and Mai (2015) that the teacher input during speaking exercises often influenced student speech performance, and teachers should always correct the students' errors positively and with motivation (Baker and Westrup 2003). 


\section{CONCLUSION}

This paper presents data from English Education Department students who completed the drama subject in the fifth semesters regarding the advantages of English drama and the factors affecting their speaking performance. The results of the study indicate that the participants faced some problems such as (1) they felt nervous to speak future in front of the public, (2) they worried about making mistakes about their pronunciation and expression, (3) they were fearful of criticism. The results also show some factors affecting their speaking performance and its benefits: (1) the participants' preparation in action, (2) lecturers' feedback and appreciation in English drama.

The implications for lecturers involved in speaking performance include drama to consider their involvement in the process of student engagement in preparing for the performance. The input and praise they receive can greatly affect students' self-confidence, self-esteem, and the results of their appearance with the preparation time.

\section{REFERENCES}

[1] Bachman, L., and Palmer, A. S. 1996. Language Testing in Practice. Oxford: Oxford University Press.

[2] Baim, C., S. Brookes, and A. Mountford. 2002. The Geese Theatre Handbook: Drama with offenders and people at risk. Winchester: Waterside Press.

[3] Baker, J., and Westrup, H. 2003. Essential Speaking Skills: A Handbook for English Language Teachers. London: Continuum.

[4] Creswell, J. W. 2012. Qualitative inquiry and research design: Choosing among five approach (3th ed). Thousand Oaks, CA: Sage.

[5] Edward, R., and Holland, J. 2013. What is Qualitative Interviewing? Bloomsbury.

Hampshire, A. 1996. The development of socio-linguistic strategies: Implications for children with speech and language impairments. Current Issues in Language and Society 3: 91-4.

[6] Jindal-Snape, D., and J. Foggie. 2008. A holistic approach to primary-secondary transitions. Improving Schools. 11: 5-18.

[7] Jindal-Snape, D., and D.J. Miller. 2010. Understanding transitions through self-esteem and reliance. In Educational transitions: Moving stories from the world, ed. D. JindalSnape, 11-32. New York: Routledge.

[8] Kempe, A. 1991. Learning both ways. British Journal of Special Education 18: 137-9.

[9] Mai, N. H. (2015). Factors Affecting Students' Speaking Performance at Le Thanh Hien High School. Asian Journal of Educational Reserach, 3.

[10] Maley, A., and Duff, A. 1978. Drama Techniques in Language Learning: Cambridge University Press.

[11] Mason, J. 2002. Qualitative Researching (2nd ed.). Sage. 
[12] Masoumi-Moghaddam, S. 2018. Using Drama and Drama Techniques to Teach English Conversations to English as A Foreign Language Learners. International Journal of Applied Linguistics \& English Literature, 7, 63-68.

[13] Peter, M. 2000a. Drama: Communicating with people learning disabilities. Journal of Nursing and Residential Care 2: 78-82.

[14] Peter, M. 2000b. Developing drama with children with autism. Good Autism Practice 1: 9-20.

[15] Peter, M. 2003. Drama, narrative and early learning. British Journal of Special Education 30: 21-7.

[16] Richard, J. C. 2008. Teaching Listening and Speaking from Theory to Practice. Cambridge: Cambridge University Press.

[17] Schnapp, L., and C. Olsen. 2003. Teaching self-advocating strategies through drama. Intervention in School and Clinic 38: 211-19.

[18] Tanveer, M. 2007. Investigation of The Factors That Cause Language Anxiety for ESL/EFL Learners in Learning Speaking Skills and The Influence It Casts on Communication in The Target Language. Dissertation, University of Glasgow. 